\title{
An Assessment of the Access to Credit-Welfare Nexus: Evidence from Mauritania
}

\author{
Alessandra Amendola ${ }^{1}$, Marinella Boccia ${ }^{1}$, Gianluca Mele $^{2} \&$ Luca Sensini $^{3}$ \\ ${ }^{1}$ Department of Economics and Statistics, University of Salerno, Fisciano (SA), Italy \\ ${ }^{2}$ World Bank, Washington, USA \\ ${ }^{3}$ Department of Management and Innovation Systems, DISA-MIS, University of Salerno, Fisciano (SA) Italy \\ Correspondence: Marinella Boccia, Department of Economics and Statistics, University of Salerno, Fisciano \\ (SA) Italy. E-mail: mboccia@unisa.it
}

Received: February 23, 2017

Accepted: August 6, 2017

Online Published: August 12, 2017

doi:10.5539/ijbm.v12n9p77

URL: https://doi.org/10.5539/ijbm.v12n9p77

\begin{abstract}
This paper evaluates the impact of access to credit from banks and other financial institutions on household welfare in Mauritania. Household level data are used to evaluate the relationship between credit access, a range of household characteristics, and welfare indicators. To address the threats of potential endogeneity, an index of household isolation is used to instrument access to credit. Evidence on the validity of the exclusion restriction is provided showing that household isolation is unrelated with households and area characteristics six years prior to the measurements on which this analysis is based. Results show that households with older and more educated heads are more likely to access financial services, as are households living in urban areas. In addition, greater financial access is associated with a reduced dependence on household production and increased investment in human capital. The policy conclusions from our analysis support strategies for expanding financial infrastructures in underserved rural areas of Mauritania.
\end{abstract}

Keywords: access to credit, household isolation level, instrumental variable, residuals

\section{Introduction}

The international literature on financial access and development has not yet identified a direct, unequivocal connection between household-level credit and improvements in poverty and inequality indicators. For example, Beck, Demirgüç-Kunt, and Levine (2007) found that financial access is correlated with lower rates of poverty and income inequality, while Honohan and King (2012) showed that the use of formal banking services is associated with an increase in individual monthly income. The World Bank's Global Financial Development Report of 2014 finds that financial inclusion plays a central role for development and poverty reduction. Considerable evidence shows that the poor benefit significantly from basic payments, savings, and insurance services; however it also highlights that microcredit experiments draw a mixed picture about the development benefits of microfinance projects targeting specific population groups.

Many studies have focused on the role of microfinance in poverty reduction, and again the positive evidence on welfare is encouraging. (Note 1) Moreover, given the locally specific nature of both poverty dynamics and microfinance institutions, evidence is difficult to compare across cases, and there is no consensus regarding the effect of microfinance on growth and inequality. Illustrating the complexity of isolating the direct antipoverty effects of microfinance, Morduch (1998) found that "the most important potential impacts [of microfinance] are thus associated with the reduction of vulnerability, not of poverty per se, [because] the consumption-smoothing [effect] appears to be driven largely by income-smoothing, not by borrowing and lending".

This paper contributes to the literature on the impact of financial access, as measured by credit from banks and other financial institutions (Note 2), on household welfare in Mauritania. The potential endogeneity of access to credit is addressed using an instrumental variable approach. The analysis draws on data from the Ongoing Survey of Household Living Conditions (Enquête Permanente sur les Conditions de Vie des Ménages, EPCV) implemented by the National Statistics Office (Office National de la Statistique, ONS). The 2014 EPCV covered 9,557 households across 13 regions (walleyes), 53 provinces (moughatas) and 647 districts.

The Mauritanian credit market is shallow, fragmented and overwhelmingly informal. Few formal credit 
providers operate in Mauritania, and most bank branches, ATMs and other financial infrastructure is confined to the capital, Nouakchott. There are also important cultural barriers to credit access-including a strong gender dimension - as well as pervasive information asymmetry between potential borrowers and lenders, and a generally poor legal and governance framework. Mauritania's informal financial sector is extensive, but produces little reliable data. Informal finance is typically offered on simple terms and frequently involves family connections, tribal affiliations or other networks of social trust. Due to data limitations this analysis concentrates exclusively on the formal credit sector.

Among the limitations of this paper is the lack of panel data. Comparing the evolution of agents over time would add valuable information; however, current data do not allow the exploitation of longitudinal dimension. For future research to address these shortfalls, it will be critical to enhance the quality and the availability of official data. In this respect, a strong political commitment and consequent financial engagement to prioritizing statistics are key prerequisites for the revitalization of the analytical efforts that can support decision-makers improving the nexus between financial access and welfare.

\section{The International Literature on Financial Access and Poverty}

Most research on the relationship between financial access and poverty relies on standard welfare indicators such as household consumption, expenditure and income. Some studies show that the use of formal banking services increases individual monthly income (Honohan \& King, 2012), while others find that financial access is associated with lower rates of poverty and inequality, inferring that the use of financial services has a disproportionately positive impact on the poor (Beck, Demirgüç-Kunt, \& Levine, 2007). There is also evidence that financial access is linked to improvements in the severity of poverty (Honohan, 2004). Research conducted in Pakistan and India reveals that the expansion of rural financial services is associated with improvements in household welfare (Khandker \& Faruqee, 2003) and that the development of bank branches increases non-agricultural economic output and reduces rural poverty (Burgess \& Pande, 2003).

Microfinance has been hailed as a vital tool for the economic empowerment of poor households. Research has shown that access to microfinance correlates with rising household income and consumption levels, less severe income inequality and enhanced welfare (Mahjabeen, 2008). Studies have found a positive relationship between household characteristics, borrowing patterns and expenditure levels (Giang et al., 2015). Substantial research has focused on the issue of endogeneity in access to credit, and studies have shown that access to credit significantly influences economic incentives at the household level, improving consumption (Pitt \& Khandker, 1998) and altering positively consumption and investment decisions and impacting rates of wage growth and capital formation (Kaboski \& Townsend, 2012).

However, not all studies have found a positive correlation between financial access and improved poverty indicators. Some analyses have failed to show a relationship between microfinance and household welfare, and find that access to credit has a limited impact on per capita incomes, food security and on the nutritional status of credit program beneficiaries (Diagne \& Zeller, 2001). Others have revealed a regressive distribution of benefits (Mosley \& Hulme, 1998). Moreover, methodological issues remain a serious concern. According to Desai, Johnson and Tarozzi (2014), "Many proponents claim that microfinance has had enormously positive effects among borrowers. However, the rigorous evaluation of such claims of success has been complicated by the endogeneity of program placement and client selection, both common obstacles in program evaluations. In this context randomized control trials provide an ideal research design to evaluate the impact." In an effort to increase the analytical rigor of financial access studies, researchers turned to randomized controlled trials. This methodology has been used to estimate the impact of access to microcredit by comparing outcomes among a random sample of individual borrowers to those of non-borrowers with similar socioeconomic characteristics. Some of these studies have found that access to finance produced measurable benefits in the form of increased employment and food consumption (Karlan \& Zinman, 2010), other have displayed a significant impact on investment by small business, on profits by pre-existing businesses, as well on expenditure in durable goods, but not on consumption (Banerjee, Duflo, Glennerster \& Kinnan, 2015). Overall, these studies provide strong empirical evidence for a positive correlation between access to finance and household welfare.

\section{Methodology}

Causal conclusions of this work rely on the ability to instrument for access to credit. (Note 3) More in general: "Microfinance institutions (MFIs) typically choose to locate in areas predicted to be profitable, and/or where large impacts are expected. In addition, individuals who seek out loans in areas served by MFIs and that are willing and able to form joint liability borrowing groups (a model often preferred by MFIs) are likely different from others who do not along a number of observable and unobservable factors. Until recently, the results of 
most evaluations could not be interpreted as conclusively causal because of the lack of an appropriate control group" (Desai, Johnson and Tarozzi 2014). In the absence of an experimental design, this issue is addressed by using the household isolation level (HIL) to instrument for access to credit. HIL is defined by using a number of indicators - self-reported by households - on the distance from various institutions and service providers. We assume that credit institutions have approximately the same average distance from households, and on these bases we move to estimate the relationships between access to credit and (i) consumption of household production, (ii) household total spending on non-durable goods and services, (iii) food spending, (iv) education spending and (v) poverty incidence.

The exclusion restriction states that the HIL affects household welfare only through its effects on access to credit. The validity of such restriction is ensured by controlling for all unobservable variables through area-level fixed effects. Unfortunately, data limitations in the panel structure of the dataset prevented us from using household-level fixed effects or longitudinal information to address the endogeneity problem. Nevertheless, this analysis provides evidence in favour of the exclusion restriction, showing that the exogenous variability was unrelated with households and with local patterns six years prior to the measurements on which this analysis is based.

\section{Country Context: Mauritania}

This section provides a broad overview of the country's characteristics and describes the patterns of the banking sector and access to finance.

\subsection{Macroeconomic Overview}

Mauritania is a Sahelian country on the West Coast of Africa with a land area of approximately 1 million square kilometers, most of which is covered by the Sahara desert, and a population of roughly 3.6 million. (Note 4) The country has urbanized rapidly since the 1960s, and its population is now largely concentrated in Nouakchott and other major cities such as Nouadhibou and Rosso.

Mauritania has experienced robust growth in recent years driven by a thriving natural resource sector and high international commodity prices. However, recent global price shocks have underscored the country's high degree of external exposure, which is magnified by a lack of diversification. Mauritania also faces exogenous vulnerabilities related to its ecology and geography, which make it especially sensitive to climate change, and it has a history of political instability, which is exacerbated by an inherently volatile system of tribal loyalties, an informal racial hierarchy, the rise of Islamic fundamentalism in the Maghreb region and persistent tensions with Morocco over Western Sahara.

Poverty is most pervasive and extreme in rural Mauritania, with some of the highest rates registered in the southern regions bordering Senegal. While overall poverty is declining, a combination of continued rural-urban migration and the volatility of the resource-based urban economy may be causing a gradual increase in urban poverty. Nevertheless, most of the country's poor are concentrated in rural areas. (Note 5) About 30 percent of those aged 15-34 are not enrolled in school and do not participate in the labor force. The capital-intensive mining sector is unable to absorb a rapidly growing number of low-skilled workers, and about 85 percent the labor force is employed in the informal economy, particularly semi-subsistence agriculture. (Note 6)

An adverse business and investment climate undermine Mauritania's economic competitiveness, slowing the growth of its small formal sector and inhibiting diversification. In the mid-2000s Mauritania's manufacturing and retail trade sectors included fewer than 250 formal firms with more than 5 employees. (Note 7) Burdensome procedures for paying taxes, resolving insolvency, starting a business, trading across borders and obtaining credit all present serious obstacles to formalization and expansion, particularly for small and medium enterprises (SMEs).

\subsection{Access to the Finance and Banking Sector}

The World Bank's Doing Business report cites access to finance as the top constraint on the Mauritanian private sector. (Note 8) The banking industry is dominated by a few very large firms, which concentrate almost exclusively on serving specific commercial and industrial groups. Prospective borrowers who do not belong to these groups face considerable difficulty in accessing financial services. (Note 9) Major firms also tend to enjoy strong political connections, which they can use to protect themselves from competition. As a result of regulatory barriers and governance issues Mauritania ranked $168^{\text {th }}$ out of 189 countries in the 2016 Doing Business report.

The 2016 Doing Business report ranked Mauritania $162^{\text {nd }}$ out of 189 countries in terms of the ease of getting credit, and its scores on several other financial indicators compare poorly with the average for Sub-Saharan Africa and most comparator countries. Information asymmetry is a major obstacle to financial access, especially 
for SMEs, as few prospective borrowers are able to present a verifiable credit history. While credit to the economy has grown rapidly, increasing by 300 percent between 2005 and 2014, financial deepening in Mauritania has been far slower than in peer countries. The financial system is dominated by banks, and its structure evolved significantly in recent years, following the establishment of the state-owned Deposit and Development Fund (Caisse de Dépôts et de Development, CDD) in 2011, and the entry of several new commercial banks, some foreign-owned.

The small size, shallowness and fragmentation of the Mauritanian financial system are major impediments to the development of financial intermediation services. The assets of the country's largest bank amount to just US\$320 million, and total banking-sector assets are estimated at less than US\$2 billion. Financial infrastructure is limited, and cash remains the most common means of payment in the domestic economy. The insurance industry and pension schemes play a very minor in the financial system, and the ability of banks to play a decisive role in supporting private-sector development is limited by nonperforming loans, which remained high at over 20 percent of total loans in 2013, though down from 45 percent in 2010.

In 2013 banking-sector assets represented 38 percent of GDP, and credit to the private sector represented 26 percent. (Note 10) The return on assets stood at 2 percent, and the return on equity was 9 percent. In recent years interest rates on credit declined from 15 percent to 10-12 percent as new banks entered the market. However, rates vary little based on counterparty, maturity or type of financing. Headline profitability is mediocre, limiting both the sector's potential for organic growth and its capacity to absorb shocks. The absence of a market for short-term liquidity is a major impediment to the development of intermediation. Indicators of access to financial services in Mauritania remain below the average for Sub-Saharan Africa.

The country's microfinance sector is similarly underdeveloped. In 2013 there were 31 registered microfinance institutions (MFIs) in Mauritania, 10 of which were in the process of losing their licenses. Most MFIs are small, and the country currently has only one large microfinance network, the Public Credit and Savings Fund Promotion Agency (L'agence de Promotion des Caisses Populaires d'Epargne et de Crédit, PROCAPEC). Nevertheless, the total number of MFI clients increased from 139,000 in 2006 to over 200,000 in 2014, and MFIs now account for about 5 percent of all loans and 2 percent of all deposits. MFI loan maturities range from 3 months to 2 years, and rates for small businesses average 16 percent. MFIs also provide savings accounts - though these are limited to very short-term non-remunerated deposits - and offer money transfers. Islamic financial products are common, especially non-interest-bearing rent-to-own agreements (murabaha), which represent over 74 percent of PROCAPEC loans. (Note 11)

Mauritania's financial sector also faces challenges relate to its geographic isolation, hard infrastructure gaps and general lack of technical capacity. Bank credit to the private sector is overwhelmingly short-term, and information asymmetry severely limits its allocative efficiency. Lack of information about potential borrower leads banks to disregard SMEs in favor of large, well-established firms. As a result, informal financing, including at the international level, is often the only option available for Mauritanian SMEs. Low individual bancarization rates represent a major additional constraint on credit access. Information technology is limited, clearing systems mostly rely on manual entry, and electronic payment instruments are seldom utilized. The government recently began preparing a credit card system in collaboration with the private sector, but this effort is still in its early stages. Finally, weak legal and judicial systems inhibits the enforcement of contracts, and the legislative framework for protecting creditors' rights is virtually nonexistent.

\section{Household Characteristics, Poverty Incidence and Credit Access}

The analysis presented below is based on the Mauritania EPCV for 2014. The survey is the result of a partnership between the ONS, the Ministry of Economic Development, the World Bank, and Afristat. The survey covers a wide range of socioeconomic variables collected through questionnaires administered to households and communities. The "basic indicators of wellbeing" module contains data on household composition, labor, education, social capital, health, access to services and credit. The "revenue and expenditure" module includes information on spending, consumption, transfers and income. The household represents the statistical unit of analysis. Of the 9,557 households surveyed in the 2014 EPCV, 55.3 percent were in urban centers and 44.7 percent were in rural areas. As a secondary source of information, the analysis is based on data from the 2008 EPCV. This household survey shares the same structure as the 2014 one, and consists of 13.738 households. The two surveys are cross-sectional representative samples of the underlying population. In the following paragraphs, a number of descriptive statistics set the stage for the main empirical analysis, which will be presented in the next section.

Mauritanian households are generally organized according to a traditional patriarchal model. Sixty-eight percent 
of households are headed by men, and 32 percent are headed by women. Household size is clearly correlated with poverty, and poverty incidence increases linearly with the number of household members. Households headed by married people tend to both include more children and are poorer than households headed by single people. Polygamy is relatively common in Mauritania, and polygamous households tend to be among the largest and poorest in the country. Poverty rates declined among all household types between the 2008 and 2014 surveys, with medium-sized households showing the greatest degree of improvement (Figure 1).

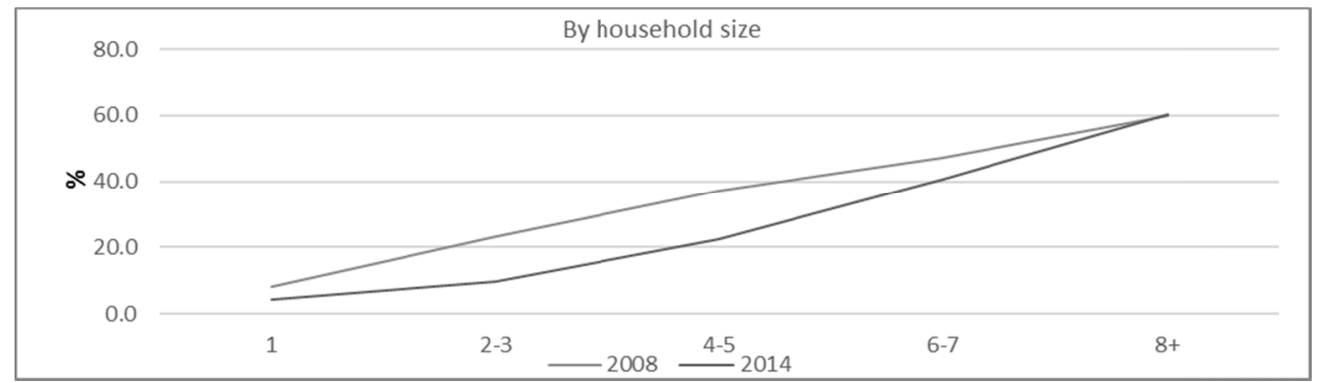

Figure 1. Poverty Incidence by Household Size

The poverty incidence does not appear to depend on the gender of the household head. Male-headed households tended to be marginally poorer both in 2008 and 2014, even when controlling for household size. The age of the head of household also appears to have no effect on poverty levels. Welfare indicators improved among all age groups in 2014, but households headed by younger people showed a more markedly positive trend (Figure 2).

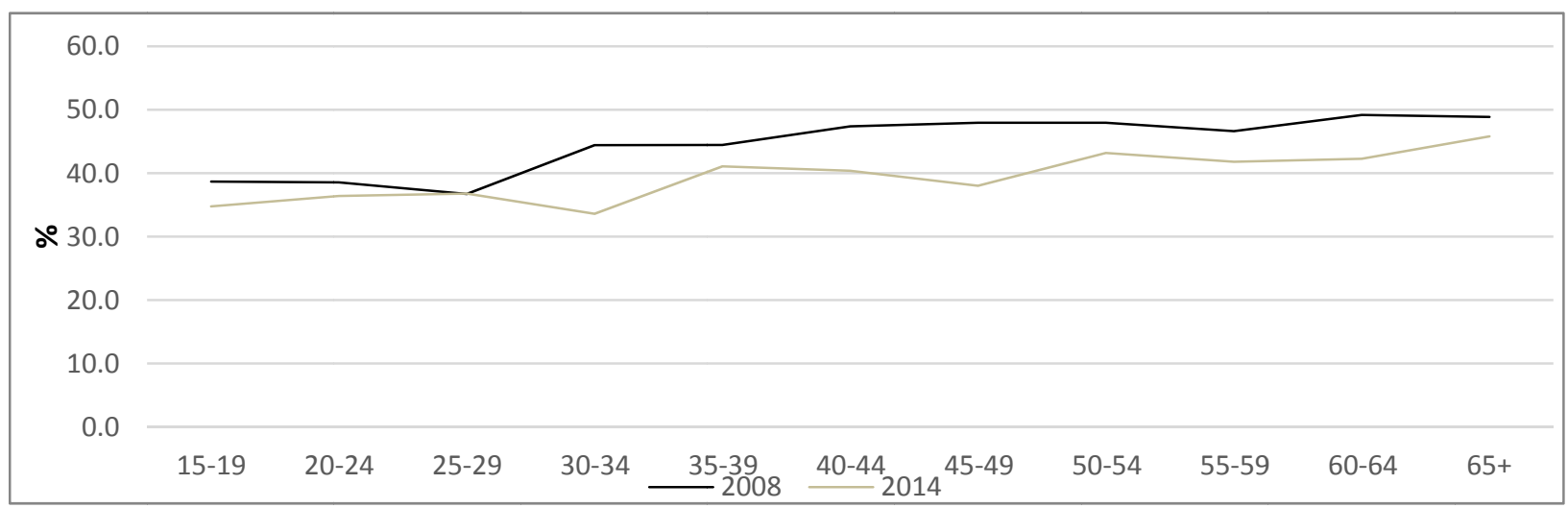

Figure 2. Poverty Incidence by age group of household head

Households headed by public employees had the lowest poverty rates. Households headed by private employees had higher rates, followed by households headed by self-employed workers outside the agricultural sector. Households headed by self-employed workers in the agricultural sector were the poorest, and their poverty incidence was even higher than that of households headed by unemployed workers or non-participants in the labor force (Figure 3). 


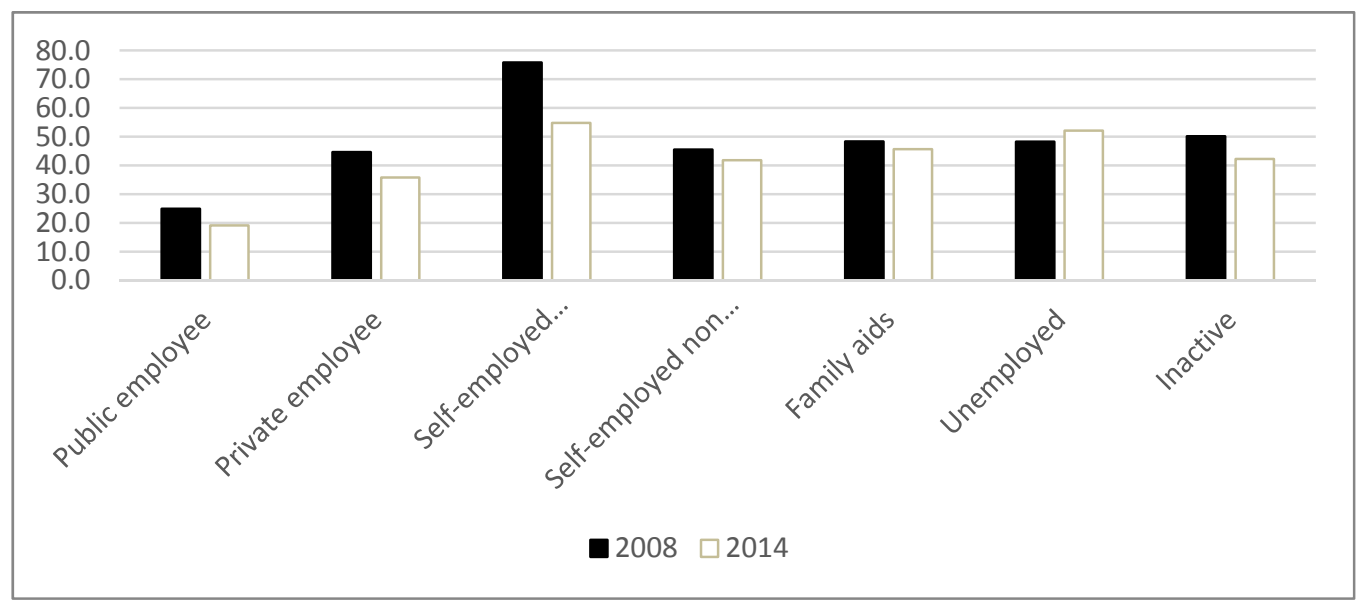

Figure 3. Poverty Incidence by Occupation

The education level of the head of household is negatively correlated with poverty incidence. Primary education is compulsory in Mauritania and lasts 6 years. Secondary school covers a period of 6 or 7 years, depending on whether the student opts for a Professional or Technical Baccalaureate, or a full Baccalaureate. Tertiary education typically lasts 3-6 years; advanced degrees are very rare and are usually obtained from the University of Nouakchott. In addition to the formal school system, traditional qur'anic schools (madrasas) are common in Mauritania. Figure 4 shows the negative correlation between education and poverty at the household level.

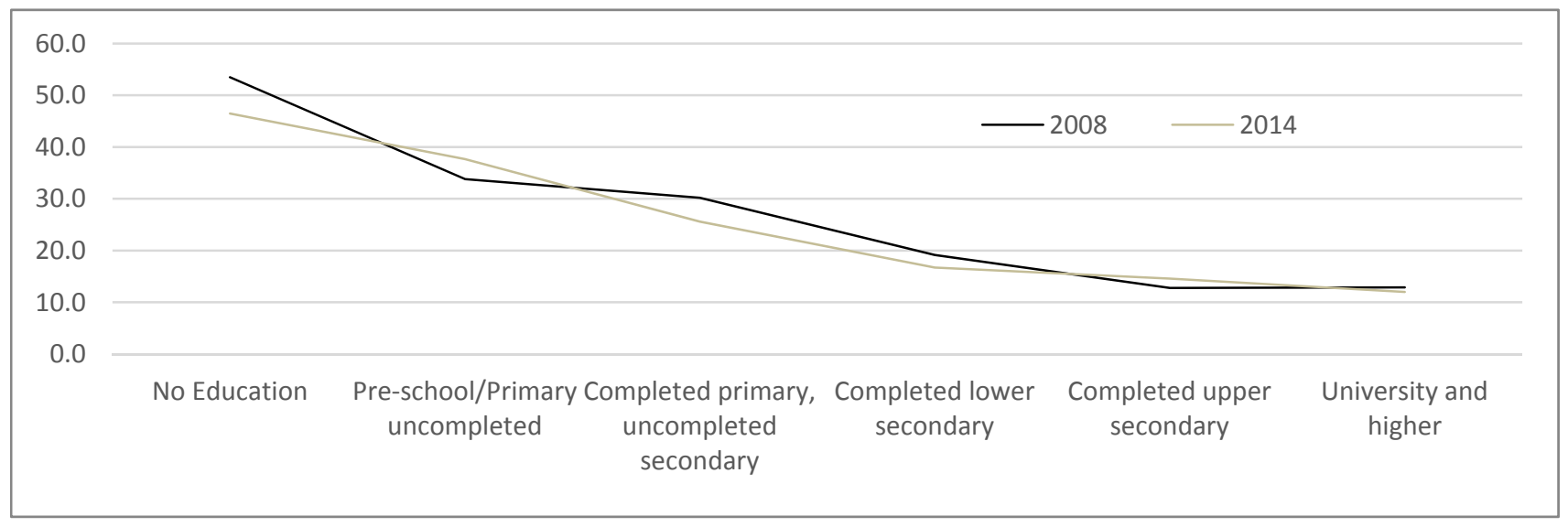

Figure 4. Poverty Incidence by Education Level of Household Head

Most importantly for the aim of this research, very few Mauritanian households have access to credit, and bank presence is almost exclusively restricted to urban areas. The EPCV includes questions designed to gauge household demand for credit during the 5 years prior to the survey. Figure 5 shows the share of households that have applied for credit from a formal financial institution, as well as the share that had their requests approved. Households applying for credit represent a tiny fraction of the population at just 5.6 percent, down from 8.8 percent in 2008. However, the likelihood of a successful credit application increased between the two surveys, rising from 3.23 percent in 2008 to 4.45 percent in 2014. Credit applications are far more common, and credit approval is far more likely, among urban households as opposed to their rural counterparts (Figure 5). Physical access to banks is even more heavily skewed in favor of urban households, about a quarter of which have access to a bank, compared to just over 1 percent of rural households (Figure 6). 


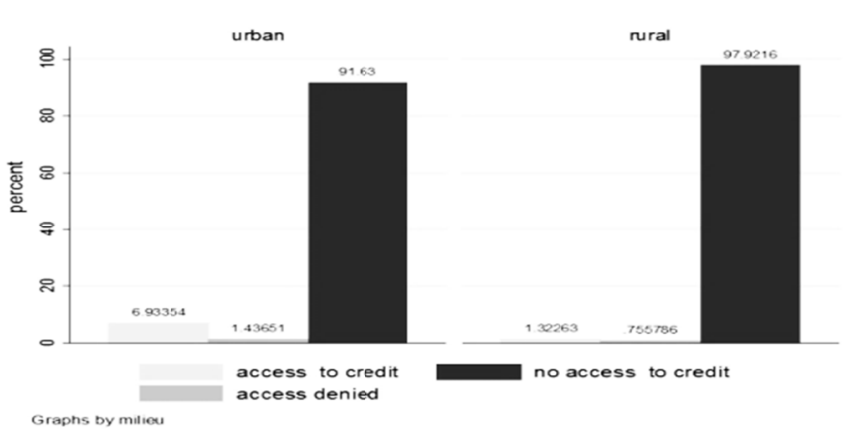

Figure 5. Credit demand by area

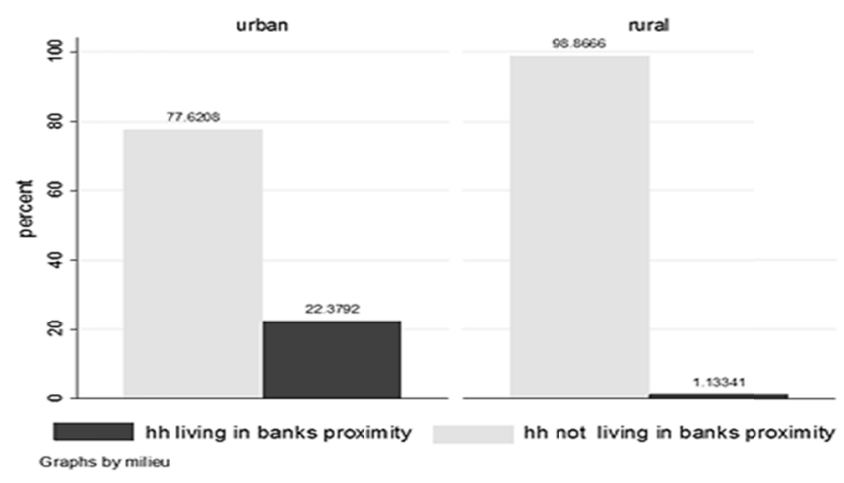

Figure 6. Percentage Households living near Banks by Area

\section{Analytical Framework}

A comprehensive understanding of household welfare requires an analysis of both income and consumption patterns. Income shocks do not always directly translate into decreased consumption or diminished welfare, and the mitigating factor may be thought of as household resilience. The ability to draw on past savings, to fall back on public assistance or to access credit to address temporary income shocks are all dimensions of resilience. Reflecting a long strand of literature (Note 12) on the importance of consumption rather than income as a primary indicator of household welfare, and taking into account the role of resilience, the analysis considers the following welfare indicators: (i) consumption (Note 13) of household production, particularly agricultural produce; (ii) total spending on nondurable goods, excluding food and education; (iii) food spending; (iv) education spending; and (v) a dummy variable representing household poverty status.

The following equation defines the parameters of interest:

$$
\Upsilon_{\mathrm{i}}=\alpha \mathrm{C}_{\mathrm{i}}+\sum_{\mathrm{v}=1}^{\mathrm{V}} \delta_{\mathrm{v}} \mathrm{X}_{\mathrm{v}, \mathrm{i}}+\mu_{\mathrm{i}}+\varepsilon_{\mathrm{i}}
$$

Where $Y_{i}$ is a dependent variable indexed to $i$ (household) and $C_{i}$ is the dummy variable indicating whether the household has accessed credit from a formal financial institution in the five years preceding the interview. In addition, $\mathrm{X}_{v, i}$ represents a set of $V=14$ households characteristics, including the number of male adults in the household, number of children, total household size, amount of land owned, and dummy variables for urban or rural location, gender, age and education level of the household head. Area-level fixed effects by province (moughata) are represented by $\mu_{i}$, and $\varepsilon_{i}$ is an error term - which is allowed to be heteroskedastic in the analysis. Standard errors are clustered on moughata. (Note 14)

\subsection{Endogeneity of Access to Credit}

The estimation of (1) is most likely affected by the endogeneity of access to credit. This may be due to a number of factors, including: (i) unobserved area-level fixed effects that influence both demand for credit and household income and consumption, such as local prices, infrastructure quality, cultural norms, environmental conditions 
and natural-disaster risks; and (ii) unmeasured household characteristics that affect both demand for credit and household income and consumption, such as the health, ability, and fecundity of household members, as well as preference heterogeneity. (Note 15) An instrumental variable strategy (IV) based on the concept of the household isolation level (HIL) is used to address the endogeneity problem. The HIL (denoted by $\mathrm{Z}_{i}$ in what follows) is computed by considering the average value of a household's distance from vital infrastructure and facilities. These include the nearest water source, primary and secondary school, government offices, transportation services, healthcare facilities, mobile phone and internet services. Results are robust to alternative sets of variables considered to compute the HIL index. (Note 16)

Table 1 shows the descriptive statistics for this indicator, along with the various components which contribute to its definition. The first two columns report the mean (in meters) and the standard deviation from the full sample. The two central columns report these same statistics for households in urban areas, while households living in rural areas are considered in the last two columns of the table.

The results show that the age, the education level of the household head as well as the household's location (whether in an urban area or not) appear to be significant determinants of credit access. Moreover, households that successfully obtain credit tend to be less dependent on the consumption of household internal production and are more likely to invest in education.

Table 1. Descriptive Statistics for the proxies Household Isolation Level (HIL)

\begin{tabular}{|c|c|c|c|c|c|c|}
\hline \multirow[b]{2}{*}{ Variables } & \multicolumn{2}{|c|}{ TOTAL SAMPLE } & \multicolumn{2}{|l|}{ URBAN } & \multicolumn{2}{|l|}{ RURAL } \\
\hline & Mean & Std dev & Mean & Std dev & Mean & Std dev \\
\hline Distance from water source & 795.4248 & 1569.986 & 446.1524 & 1049.099 & 1228.571 & 1953.639 \\
\hline Distance from transportation service & 1848.723 & 2421.069 & 827.8833 & 1462.304 & 3128.778 & 2573.088 \\
\hline Distance from primary school & 1353.707 & 1999.793 & 1060.65 & 1655.723 & 1721.311 & 2308.066 \\
\hline Distance from secondary school & 3420.595 & 2654.543 & 1837.693 & 2206.809 & 5403.926 & 1646.502 \\
\hline Distance from healthcare facility & 3201.083 & 2644.932 & 2153.571 & 2340.462 & 4517.591 & 2404.349 \\
\hline Distance from government office & 4034.412 & 2503.113 & 2905.743 & 2525.988 & 5454.604 & 1576.805 \\
\hline $\begin{array}{l}\text { Distance from mobile phone and internet } \\
\text { service }\end{array}$ & 3911.923 & 2629.179 & 2552.726 & 2606.349 & 5615.555 & 1356.178 \\
\hline Household isolation level & $6.75 \mathrm{e}-09$ & 1.740801 & -.9687785 & 1.469942 & 1.214924 & 1.208036 \\
\hline
\end{tabular}

\subsection{Validity of the Exclusion Restriction}

The HIL index is regarded as a determinant for access to banks and other financial institutions. (Note 17) The location of household in rural and urban areas may follow from sorting along unobservable dimensions. Because of this, household isolation can be itself endogenous in our model, thus invalidating the exclusion restriction needed for identification. The instrumental variation employed here is the residual variability in HIL after netting off the area unobservables and characteristics of the households living in those areas.

To see this, the first stage equation is:

$$
C_{i}=\beta Z_{i}+\sum_{v=1}^{V} \gamma_{v} X_{v, i}+\mu_{i}+\varepsilon_{i}
$$

Which relates the dummy for access to credit to HIL controlling for the same variables already included in equation (1). The parameter $\beta$ is estimated from the residual variability of the instrument, $Z_{i}$, after controlling for household characteristics and the area fixed effects. The extent of this variability in the data can be investigated by taking into account the residuals from the following equation:

$$
Z_{i}=\sum_{v=1}^{V} \partial_{v} X_{v, i}+\mu_{i}+\varepsilon_{i},
$$

Residuals are plotted in Figure 7. The HIL index presents variability that is not fully explained by the control variables included in equation (2). Most importantly, it appears that also in rural areas households can be marginally worse off and, presumably, less likely to have access to formal credit. 
a)

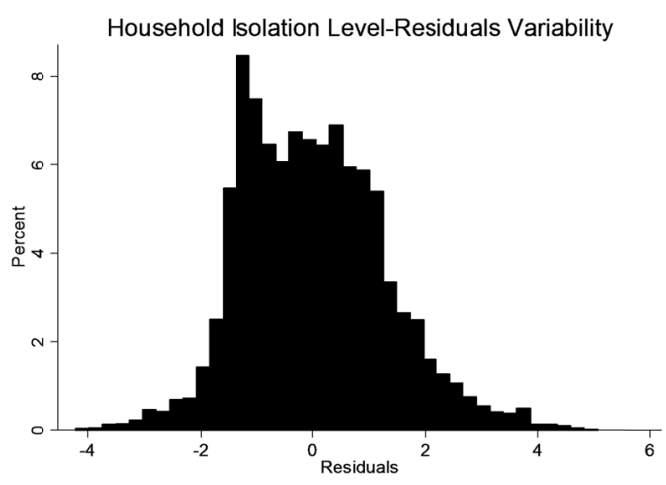

b)

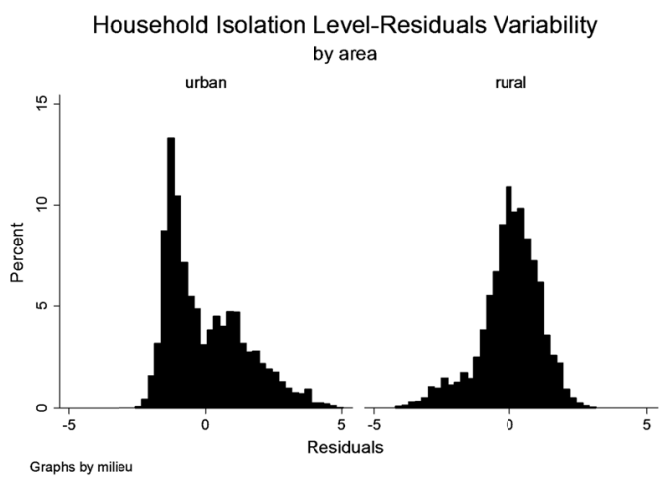

Figure 7. Household Isolation Level Residuals Variability

The variability of residuals in equation (3) is a necessary condition for the identification, but does not make the exclusion restriction bulletproof. In an effort to address this problem, we turn to data from the $2008 \mathrm{EPCV}$ and show that residuals in Figure 7 are not predicted by past area and household characteristics. This is shown in Figure 8, where access to credit is considered, along with a set of other variables, over the period 2003-2008. The lack of panel data on household across the two waves (2008 and 2014) forces the analysis at the area (moughata) level. We probe empirically the validity of instrument computing the estimation (Note 18) of the average value of residuals $E_{a}^{2014}$-in area-(Note 19) on the average value of the variables measured in 2008, $E_{a}^{2008}$. More in details, we consider the relationship between the residuals and a number of indicators, such as: educational indicators at different levels, the percentage of households located in urban areas, the average age of the household head, the percentage of households that had access to credit in 2008 and the average value of expenditure on non-durable goods.

The following equation is then estimated:

$$
E_{a}^{2014}=\alpha+\rho E_{a}^{2008}+\varepsilon_{a}
$$

Table 2 reports the results related to the estimation of equation (4) and shows that the residuals in 2014 are orthogonal to the outcomes measured in 2008. The coefficients are equal to zero or not significant. In addition, Figure 8 reports the scatterplot of these two variables, with a superimposed linear fit from the same regression. The figure offers little evidence of correlation with past characteristics, thus corroborating the exogeneity of the instrument used in the main equation.

Table 2. Residuals in 2014 on Outcomes in 2008- OLS Estimate

\begin{tabular}{|c|c|c|c|}
\hline Variables_ & Residuals-2014-moughata & R-squared & Observations \\
\hline Age head-moughata & $\begin{array}{l}-0 \\
(1.86 \mathrm{e}-10)\end{array}$ & 0.000 & 50 \\
\hline Urban-moughata & $\begin{array}{l}-5.26 \mathrm{e}-10 \\
(1.45 \mathrm{e}-09)\end{array}$ & 0.004 & 50 \\
\hline Non-durable-expenditure-moughata & $\begin{array}{l}-0 \\
(0)\end{array}$ & 0.010 & 50 \\
\hline Primary school-moughata & $\begin{array}{l}-7.16 \mathrm{e}-09 \\
(1.06 \mathrm{e}-08)\end{array}$ & 0.012 & 50 \\
\hline Secondary-school-moughata & $\begin{array}{l}-3.66 \mathrm{e}-10 \\
(7.96 \mathrm{e}-09)\end{array}$ & 0.000 & 50 \\
\hline Traditional ed. -moughata & $\begin{array}{l}4.56 \mathrm{e}-10 \\
(1.99 \mathrm{e}-09)\end{array}$ & 0.001 & 50 \\
\hline High school-moughata & $\begin{array}{l}5.92 \mathrm{e}-09 \\
(1.33 \mathrm{e}-08)\end{array}$ & 0.007 & 50 \\
\hline Access to credit-moughata & $\begin{array}{l}5.46 \mathrm{e}-09 \\
(1.58 \mathrm{e}-08)\end{array}$ & 0.002 & 50 \\
\hline
\end{tabular}

Note. The treatment variables are the average value of the head age, the percentage households located in urban area; the percentage of household head educated at primary school, secondary school, traditional level and high school; the average value of non-durable expenditure; the percentage of households that have access to credit. All the variables are at moughataa level. Standard errors in parentheses. *** Significant at the 1 percent level. ** Significant at the 5 percent level. * Significant at the 10 percent level. 


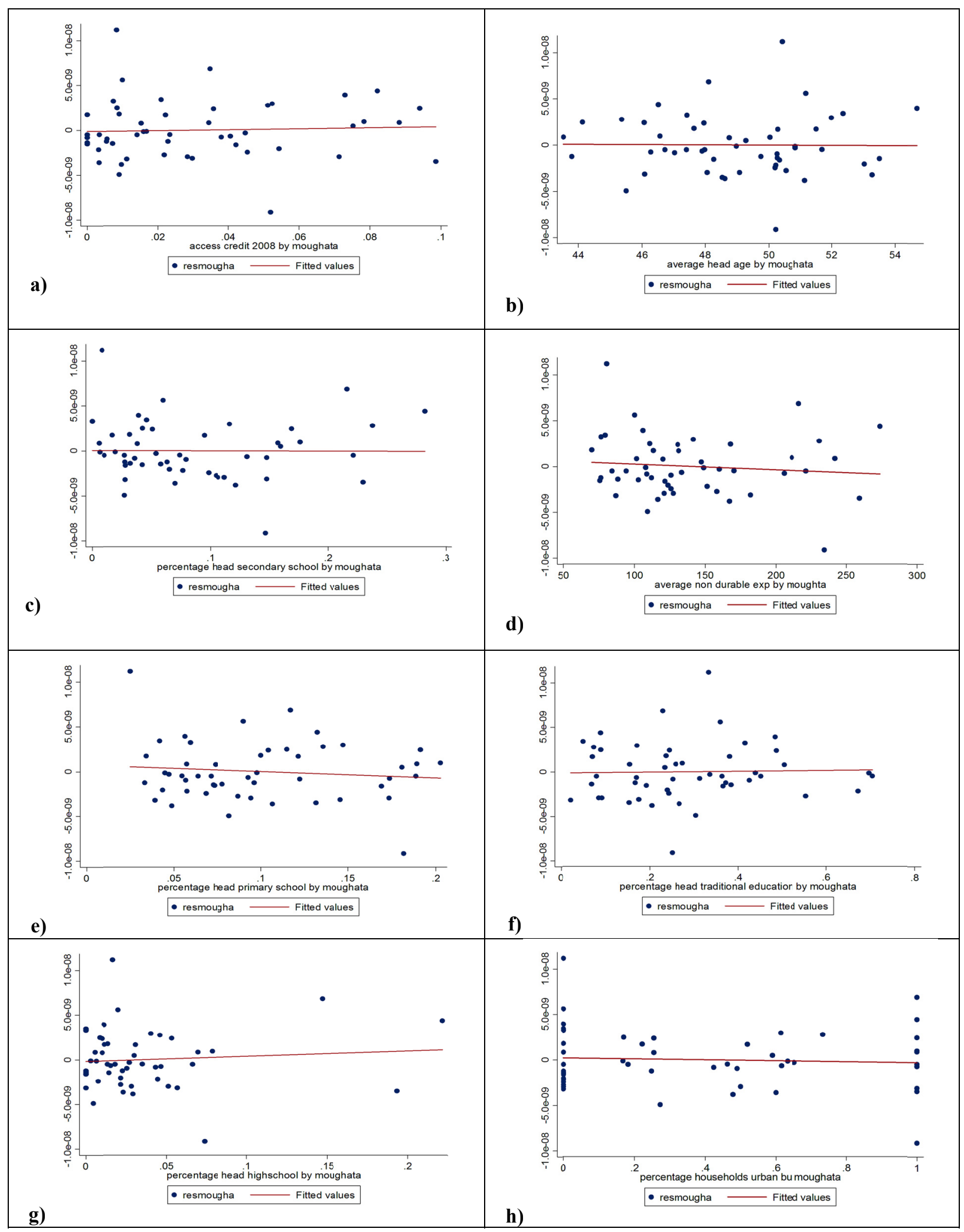

Figure 8. Residuals for 2014 Compared with Outcomes for 2008, Average Values by Moughata

\section{Results}

Table 3 and Table 4_provide a probit estimation of Equation 2. The analysis is clustered by moughata, and robust standard errors are reported throughout. The results show that HIL is negatively correlated with access to credit (Table 3). The coefficients are statistically significant and economically meaningful, and the results are robust to 
the inclusion of the household characteristics (Table 4). The age and education level of the head of household and the household's location in an urban area have especially positive and significant effects on the probability of accessing credit. Estimates of $\beta$ are presented along with standard errors, and statistical significance at the 1, 5 and 10 percent levels is noted.

Table 3. Probit Estimate of HIL and Access to Credit

\begin{tabular}{ll}
\hline Variables & Access to credit \\
\hline Households isolation level & $-0.126^{* * *}$ \\
& $(0.0336)$ \\
Constant & $-2.039^{* * *}$ \\
& $(0.0278)$ \\
Observations & 8,663 \\
\hline
\end{tabular}

Note. The treatment variable is the household isolation level (HIL).Standard errors are clustered by moughata

*** Significant at the 1 percent level. ** Significant at the 5 percent level. * Significant at the 10 percent level.

Table 4. Probit Estimate of HIL and Access to Credit

\begin{tabular}{|c|c|}
\hline Variables & Access to credit \\
\hline \multirow[t]{2}{*}{ Household isolation level } & $-0.0871 * * *$ \\
\hline & $(0.0334)$ \\
\hline \multirow[t]{2}{*}{ Land ownership } & -0.0671 \\
\hline & $(0.534)$ \\
\hline \multirow[t]{2}{*}{ Age head } & $0.0405^{* * *}$ \\
\hline & $(0.0140)$ \\
\hline \multirow[t]{2}{*}{ Urban } & $0.321 * *$ \\
\hline & $(0.127)$ \\
\hline \multirow[t]{2}{*}{ Number of males } & 0.0269 \\
\hline & $(0.0242)$ \\
\hline \multirow[t]{2}{*}{ Age household } & -0.00169 \\
\hline & $(0.00336)$ \\
\hline \multirow[t]{2}{*}{ Age head square } & $-0.000359 * * *$ \\
\hline & $(0.000135)$ \\
\hline \multirow[t]{2}{*}{ Number of kids } & 0.00547 \\
\hline & $(0.0382)$ \\
\hline \multirow[t]{2}{*}{ Head female } & -0.0164 \\
\hline & $(0.0757)$ \\
\hline \multirow[t]{2}{*}{ Traditional ed. } & -0.00707 \\
\hline & $(0.114)$ \\
\hline \multirow[t]{2}{*}{ Primary school } & $0.351^{* *}$ \\
\hline & $(0.168)$ \\
\hline \multirow[t]{2}{*}{ Secondary school } & $0.682 * * *$ \\
\hline & $(0.139)$ \\
\hline \multirow[t]{2}{*}{ Secondary tec-prof } & $0.877 * *$ \\
\hline & $(0.381)$ \\
\hline \multirow[t]{2}{*}{ High school } & $1.078 * * *$ \\
\hline & $(0.148)$ \\
\hline \multirow[t]{2}{*}{ Size } & -0.00642 \\
\hline & $(0.0165)$ \\
\hline \multirow[t]{2}{*}{ Constant } & $-3.304 * * *$ \\
\hline & $(0.353)$ \\
\hline Observations & 8,663 \\
\hline
\end{tabular}

Note. The treatment variable is the household isolation level (HIL). The independent variables are a dummy for urban location and for 
education level, household size, a dummy for female head of household, land ownership, number of adult males, number of children, age of household head, age of household head squared, average age of household members, and area-level fixed effects. Standard errors are clustered by moughata.

*** Significant at the 1 percent level. ** Significant at the 5 percent level. * Significant at the 10 percent level

Table 5 and Table 6 present the reduced form (RF) estimates. They show that the HIL is positively correlated with the consumption of household production and poverty incidence and negatively correlated with education spending. These results are robust to the inclusion of all other household characteristics defined in the analysis.

Table 5. Impact of HIL on Welfare-RF Estimates

\begin{tabular}{llllll}
\hline Variables & Auto-consumption & Non-durable-expenditure & Food-expenditure & Education-expenditure & Poverty \\
\hline Household isolation level & $5.799 * * *$ & $-14.87^{* * *}$ & -5.181 & $-6.512^{* * *}$ & $0.0308^{* * *}$ \\
& $(0.938)$ & $(4.699)$ & $(4.067)$ & $(1,149)$ & $(0.00614)$ \\
Constant & $36.40^{* * *}$ & $373.2^{* * *}$ & $347.3^{* * *}$ & $76.63^{* * *}$ & $0.213^{* * *}$ \\
& $(0.00710)$ & $(0.0356)$ & $(0.0308)$ & $(0.00870)$ & $(4.65 \mathrm{e}-05)$ \\
Observations & 9,472 & 9,472 & 9,472 & 9,472 & 9,472 \\
R-squared & 0.063 & 0.161 & 0.085 & 0.067 & 0.112 \\
\hline
\end{tabular}

Note. The treatment variable is the household isolation level (HIL). Standard errors are clustered by moughata

*** Significant at the 1 percent level. ** Significant at the 5 percent level. * Significant at the 10 percent level.

Table 6. Impact of HIL on Welfare-RF Estimates

\begin{tabular}{|c|c|c|c|c|c|}
\hline Variables & Auto-consumption & Non-durable-expenditure & Food-expenditure & Education-expenditure & Poverty \\
\hline \multirow[t]{2}{*}{ Household isolation level } & $3.915 * * *$ & -3.920 & 1.408 & $-3.575^{* * *}$ & $0.0161 * * *$ \\
\hline & $(1.089)$ & $(4.654)$ & $(4.351)$ & $(0.767)$ & $(0.00463)$ \\
\hline \multirow[t]{2}{*}{ Land ownership } & $45.23 * * *$ & -48.83 & 6.172 & -5.642 & 0.0248 \\
\hline & $(15.01)$ & $(31.08)$ & $(26.86)$ & $(23.65)$ & $(0.0436)$ \\
\hline \multirow[t]{2}{*}{ Age head } & $1.240 * * *$ & 0.291 & 1.455 & $2.665^{* * *}$ & $-0.00377 *$ \\
\hline & $(0.362)$ & $(1.080)$ & $(0.975)$ & $(0.390)$ & $(0.00193)$ \\
\hline \multirow{2}{*}{ Urban } & $-19.91 * *$ & $98.18^{* * *}$ & $58.92 * * *$ & $11.06 * * *$ & $-0.143 * * *$ \\
\hline & $(8.702)$ & $(18.21)$ & $(15.54)$ & $(3.108)$ & $(0.0233)$ \\
\hline \multirow[t]{2}{*}{ Number of males } & 0.727 & -0.586 & -0.419 & 0.676 & $0.0112 * * *$ \\
\hline & $(0.700)$ & $(1.862)$ & $(1.485)$ & $(0.738)$ & $(0.00398)$ \\
\hline \multirow[t]{2}{*}{ Age household } & 0.108 & $1.324 * * *$ & $1.229 * * *$ & $-1.872 * * *$ & -0.000933 \\
\hline & $(0.148)$ & $(0.419)$ & $(0.448)$ & $(0.159)$ & $(0.000989)$ \\
\hline \multirow[t]{2}{*}{ Age head square } & $-0.0112 * * *$ & -0.00898 & $-0.0183 * *$ & $-0.0175 * * *$ & $3.71 \mathrm{e}-05^{* *}$ \\
\hline & $(0.00340)$ & $(0.00899)$ & $(0.00789)$ & $(0.00313)$ & $(1.75 \mathrm{e}-05)$ \\
\hline \multirow[t]{2}{*}{ Number of kids } & $-3.219 * *$ & -4.338 & $-7.833 * * *$ & $-21.59 * * *$ & $0.0292 * * *$ \\
\hline & $(1.492)$ & $(2.684)$ & $(2.614)$ & $(1.520)$ & $(0.00686)$ \\
\hline \multirow{2}{*}{ Head Female } & -4.574 & 2.849 & 0.353 & $10.61 * * *$ & 0.00822 \\
\hline & $(3.771)$ & $(5.655)$ & $(5.858)$ & $(2.021)$ & $(0.00960)$ \\
\hline \multirow[t]{2}{*}{ Traditional ed. } & 2.678 & $15.27^{*}$ & 13.04 & 4.266 & -0.0109 \\
\hline & (4.194) & $(8.769)$ & (8.699) & $(2.769)$ & $(0.0159)$ \\
\hline \multirow[t]{2}{*}{ Primary school } & -0.580 & $28.92 * *$ & 19.66 & $20.73 * * *$ & $-0.0346^{*}$ \\
\hline & $(4.902)$ & (13.66) & (13.19) & $(3.055)$ & $(0.0191)$ \\
\hline \multirow[t]{2}{*}{ Secondary school } & -0.778 & $66.63 * * *$ & $39.44 * * *$ & $25.06 * * *$ & $-0.0851 * * *$ \\
\hline & $(4.788)$ & $(12.91)$ & (12.23) & $(4.060)$ & $(0.0186)$ \\
\hline \multirow[t]{2}{*}{ Secondary tec-prof } & -6.677 & $117.9^{* *}$ & 61.93 & $21.35^{* * *}$ & $-0.103 * * *$ \\
\hline & $(13.35)$ & $(57.05)$ & $(44.67)$ & $(5.134)$ & $(0.0335)$ \\
\hline \multirow[t]{2}{*}{ High school } & 1.597 & $99.94 * * *$ & $53.16 * *$ & $41.78 * * *$ & $-0.114 * * *$ \\
\hline & $(8.110)$ & $(30.46)$ & $(25.83)$ & $(5.373)$ & $(0.0224)$ \\
\hline \multirow[t]{2}{*}{ Size } & -0.0486 & $-10.55^{* * *}$ & $-9.144 * * *$ & $11.91 * * *$ & $0.0383 * * *$ \\
\hline & $(0.496)$ & $(1.716)$ & $(1.732)$ & $(0.714)$ & $(0.00600)$ \\
\hline
\end{tabular}




\begin{tabular}{llllll}
\hline Constant & 13.38 & $334.3^{* * *}$ & $302.0^{* * *}$ & $-34.00^{* * *}$ & $0.155^{* * *}$ \\
& $(11.82)$ & $(31.72)$ & $(30.31)$ & $(7.054)$ & $(0.0499)$ \\
Observations & 9,472 & 9,472 & 9,472 & 9,472 & 9,472 \\
R-squared & 0.067 & 0.216 & 0.122 & 0.390 & 0.262 \\
\hline
\end{tabular}

Note. The treatment variable is the household isolation level (HIL). The independent variables are a dummy for urban location and for education level, household size, a dummy for female head of household, land ownership, number of adult males, number of children, age of household head, age of household head squared, average age of household members, and area-level fixed effects. Standard errors are clustered by moughata.

*** Significant at the 1 percent level. ** Significant at the 5 percent level. * Significant at the 10 percent level.

Table 7 and Table 8 present Instrumental Variable (IV) estimates of the relationship between access to credit and the key variables used in the analysis. Estimates of $\alpha$ are reported along with standard errors, and statistical significance at the 5 and 10 percent levels is noted.

Table 7. Impact of Access to Credit on Welfare - Instrumental Variable (IV) Estimates

\begin{tabular}{|c|c|c|c|c|c|}
\hline Variables & Auto-consumption & Non-durable-expenditure & Food-expenditure & Education-expenditure & Poverty \\
\hline \multirow[t]{2}{*}{ Access to credit } & $-522.2 * *$ & $1,349^{*}$ & 474.7 & $586.9^{* * *}$ & $-2.795 * *$ \\
\hline & $(212.5)$ & $(752.0)$ & $(446.6)$ & $(225.0)$ & $(1.329)$ \\
\hline \multirow[t]{2}{*}{ Constant } & $51.13^{* * *}$ & $377.7 * * *$ & $387.4 * * *$ & $44.45 * * *$ & $0.270 * * *$ \\
\hline & $(3.184)$ & (11.27) & $(6.691)$ & $(3.371)$ & $(0.0199)$ \\
\hline Observations & 9,455 & 9,455 & 9,455 & 9,455 & 9,455 \\
\hline
\end{tabular}

Note. The treatment variable is the access to credit. The instrument used is HIL. Standard errors are clustered by moughata.

*** Significant at the 1 percent level. ** Significant at the 5 percent level. * Significant at the 10 percent level.

Table 8. Impact of Access to Credit on Welfare - IV Estimates

\begin{tabular}{|c|c|c|c|c|c|}
\hline Variables & Auto-consumption & Non-durable-expenditure & Food-expenditure & Education-expenditure & Poverty \\
\hline \multirow[t]{2}{*}{ Access to credit } & $-506.4 *$ & 524.4 & -168.2 & $464.0^{* *}$ & -2.116 \\
\hline & $(264.3)$ & $(725.2)$ & $(540.5)$ & (230.7) & $(1.421)$ \\
\hline \multirow[t]{2}{*}{ Land ownership } & $51.40^{* *}$ & -55.12 & 8.301 & -11.31 & 0.0506 \\
\hline & $(20.87)$ & $(35.15)$ & $(26.26)$ & (29.10) & $(0.0500)$ \\
\hline \multirow[t]{2}{*}{ Age head } & $2.608 * * *$ & -1.186 & 1.856 & 1.419 & 0.00206 \\
\hline & $(1.011)$ & $(2.337)$ & $(1.807)$ & $(0.998)$ & $(0.00496)$ \\
\hline \multirow[t]{2}{*}{ Urban } & -12.72 & $90.44 * * *$ & $61.06 * * *$ & 4.458 & $-0.112 * * *$ \\
\hline & $(11.16)$ & (24.79) & (20.13) & $(4.652)$ & $(0.0336)$ \\
\hline \multirow[t]{2}{*}{ Number of males } & 1.756 & -1.715 & -0.121 & -0.276 & $0.0155^{* *}$ \\
\hline & $(1.555)$ & (3.177) & $(1.967)$ & $(1.322)$ & $(0.00710)$ \\
\hline \multirow[t]{2}{*}{ Age household } & 0.0387 & $1.381 * * *$ & $1.197 * * *$ & $-1.809^{* * *}$ & -0.00121 \\
\hline & $(0.191)$ & $(0.446)$ & $(0.461)$ & $(0.182)$ & $(0.00118)$ \\
\hline \multirow[t]{2}{*}{ Age head square } & $-0.0228 * *$ & 0.00364 & -0.0217 & -0.00694 & $-1.26 \mathrm{e}-05$ \\
\hline & $(0.00901)$ & $(0.0192)$ & $(0.0150)$ & $(0.00874)$ & $(4.27 \mathrm{e}-05)$ \\
\hline \multirow[t]{2}{*}{ Number of kids } & -2.514 & $-5.113^{*}$ & $-7.661 * * *$ & $-22.28 * * *$ & $0.0319 * * *$ \\
\hline & $(2.050)$ & $(2.891)$ & $(2.868)$ & (1.975) & $(0.00881)$ \\
\hline \multirow[t]{2}{*}{ Head female } & -6.306 & 4.525 & -0.329 & $12.05^{* * *}$ & 0.00117 \\
\hline & $(5.264)$ & $(6.982)$ & $(5.831)$ & (3.978) & $(0.0178)$ \\
\hline \multirow[t]{2}{*}{ Traditional ed. } & -0.826 & $19.00 *$ & 11.94 & 7.399 & -0.0258 \\
\hline & $(6.471)$ & $(10.36)$ & $(8.975)$ & (5.114) & $(0.0238)$ \\
\hline \multirow[t]{2}{*}{ Primary school } & 9.074 & 19.36 & 23.18 & 11.74 & 0.00554 \\
\hline & $(9.644)$ & (20.88) & $(18.31)$ & (7.987) & $(0.0432)$ \\
\hline \multirow[t]{2}{*}{ Secondary school } & $34.19 *$ & 30.52 & 51.15 & -7.154 & 0.0613 \\
\hline & $(20.11)$ & $(54.55)$ & (41.67) & (18.79) & $(0.108)$ \\
\hline \multirow[t]{2}{*}{ Secondary tec-prof } & 48.00 & 61.21 & 80.14 & -28.89 & 0.125 \\
\hline & $(54.49)$ & $(110.8)$ & $(85.59)$ & $(46.78)$ & $(0.248)$ \\
\hline
\end{tabular}




\begin{tabular}{llllll}
\hline High school & $87.59^{* *}$ & 10.85 & 82.01 & -36.62 & 0.244 \\
& $(44.39)$ & $(123.2)$ & $(95.78)$ & $(37.26)$ & $(0.238)$ \\
Size & -0.437 & $-10.14^{* * *}$ & $-9.256^{* * *}$ & $12.28^{* * *}$ & $0.0367^{* * *}$ \\
& $(0.806)$ & $(2.169)$ & $(1.721)$ & $(0.864)$ & $(0.00766)$ \\
Constant & -13.80 & $443.7^{* * *}$ & $376.4 * * *$ & -22.14 & -0.0386 \\
& $(24.45)$ & $(53.02)$ & $(45.73)$ & $(22.29)$ & $(0.103)$ \\
Observations & 9,455 & 9,455 & 9,455 & 9,455 & 9,455 \\
\hline
\end{tabular}

Note. The treatment variable is the access to credit. The instrument used is HIL. The independent variables are a dummy for urban location and for education level, household size, a dummy for female head of household, land ownership, number of adult males, number of children, age of household head, age of household head squared, average age of household members, and area-level fixed effects. Standard errors are clustered by moughata..

*** Significant at the 1 percent level. ** Significant at the 5 percent level. * Significant at the 10 percent level.

Table 7 indicates a strong negative correlation between access to credit and both consumption of household production and poverty incidence, as well as a similarly strong positive correlation with spending on non-durable goods and services and education. Table 8 presents IV estimates for the same outcomes broken down by household characteristics, which underscores the negative correlation with consumption of household production and the positive correlation with education spending. Food spending is not significantly higher among households with access to finance, which is likely due to the relative inelasticity of food spending in general. Also, results highlight a positive but not significant effect of access to credit on poverty reduction as well as on non-durable expenditure.

In addition table 8 presents the Instrumental Variable estimation of access to credit on welfare also vis-à-vis a number of household-level variables. Consumption of household production correlates with land size, almost certainly reflecting a focus on agriculture. Spending on non-durable goods and services and food spending are both higher among urban households, while poverty incidence is lower. Education spending tends to be higher among female-headed households. All expenditure variables decrease as the number of children increases.

\section{Conclusions}

The first-degree analysis of the relationship between access to credit and household welfare in Mauritania presented above yields a number of insights with potential policy applications. The analysis begins by confirming the intuitive conclusion that household isolation is negatively correlated with access to credit. The related coefficients are statistically significant and economically meaningful, even when controlling for other household characteristics. It seems worth stressing that the objective of the paper is to provide a strong econometric framework - for the first time- to investigate the linkage between welfare and finance access in Mauritania. The choice of a variable related to spatial distance (and, in particular, used as an instrumental variable) represents an innovation in the access to credit literature. Interestingly, after controlling for endogeneity, the paper also finds no significant effects of access to credit on the actual poverty rate nor on non-durable goods consumption.

The analysis also finds that the age and education level of the head of household and the household's location in an urban area appear to be significant determinants of credit access. This is particularly relevant in the Mauritanian context, where urbanization rates have vastly outpaced improvements in education indicators. Were any further argument required in favor of strengthening the coverage and the quality of education in Mauritania, these findings provide statistical evidence that greater educational attainment appears to positively affect access to credit. In fact, some of the strongest correlations with welfare are identified by this paper with the levels of education, and in particular it appears clear that individuals with secondary and high school education enjoy better conditions vis-à-vis non-durable and food expenditure and are less poor (Figure 4).

Moreover, households that successfully obtain credit tend to be less dependent on the consumption of household production and are more likely to invest in education. The former implies higher living standards, greater food security and denser integration into the nonagricultural economy. The latter, meanwhile, suggests a special preference for investment in human capital, which may be a cause, effect or corollary of a household-level predisposition toward other forms of economic investment.

Finally, the results of this analysis present cause for Mauritanian policy makers to consider strategies for expanding financial infrastructure in underserved rural areas. Provided that progress is achieved in the viability and solvency ratios of the sector (namely by concretely addressing the issues of operational risks, access to 
reliable credit information, capacity, and poor supervision) an improvement of access to financial services and microcredit programs beyond the country's urban centers may increase inclusion by facilitating rural households' chances of obtaining credit. At present, a household's location in an urban area appears to have a differential impact on credit access, even controlling for other factors. Recent advances in mobile banking technology are already expanding access to finance in underserved areas throughout Sub-Saharan Africa. In this context, infrastructure investment and regulatory reforms designed to encourage the development of financial services in rural areas, particularly combined with efforts to enhance educational service, could spur productivity growth and support welfare improvements among the poorest and most vulnerable households in the country.

\section{References}

Armendáriz, B., \& Morduch, J. (2010). The economics of microfinance (2nd ed.). Cambridge MA.: The MIT press.

Attanasio, O., Battistin, E. \& Padula, M. (2010). Inequality and Living Standards since 1980. American Enterprise Institute for Public Policy Research Press. http://hdl.handle.net/10278/22684

Banerjee, A., Duflo, E., Glennerster, R., \& Kinnan, C. (2015). The miracle of Microfinance? Evidence from a Randomized Evaluation. American Economic Journal: Applied Economics, 7(1), 22-53. http://dx.doi.org/10.1257/app.20130533

Beck, T., Demirgüç-Kunt, A., \& Levine, R. (2007). Finance, Inequality and Poor: Cross Country Evidence. Journal of Economic Growth, 12(1), 27-49. http:// doi.org/10.1007/s10887-007-9010-6

Becker, A., \& Woessmann, L. (2009). Was Weber Wrong? A Human Capital Theory of Protestant Economic History. The Quarterly Journal of Economics, 124(2), 531-596. https://doi.org/10.1162/qjec.2009.124.2.531

Boonperm,J., Haughton, J., \& Khandker, S. R. (2013). Does the Village Fund matter in Thailand? Evaluating the impact on incomes and spending. Journal of Asian Economies, 25, 3-16. http://dx.doi.org/10.1016/j.asieco.2013.01.001

Burgess, R., \& Pande, R. (2003). Do rural banks matter? Evidence from the Indian social banking experiment. The American Economic Review, 95(3), 780-795. http://dx.doi.org/10.1257/0002828054201242

Ciang, T. T., Wang, G., \& Chien, N. D. (2015). How Credit affects the poor household Expenditure? A case study of Vietnam. Journal of Finance and Economics, 3(1), 31-43. http://dx.doi.org/10.12735/jfe.v3i1p31

Diagne, A., \& Zeller, M. (2001). Access to Credit and its Impact on Welfare in Malawi. International Food Policy Research Institute. Research Report, 116.

Desai, J., Johnson, K., \& Tarozzi, A. (2015). The Impacts of Microcredit: Evidence from Ethiopia. American Economic Journal: Applied Economics, 7(1), 54-89. http://dx.doi.org/10.1257/app.20130475

Honohan, P. (2004). Financial Development, Growth and Poverty: How Close Are the Links? (World Bank Policy Research Working Paper 3023). Washington, D.C.: The World Bank. http://hdl.handle.net/10986/14439

Honohan, P., \& M. King (2012). Cause and Effects Access: Cross-Country Evidence from the Finscope Survey. IIIS Discussion paper No.339.

Kaboski, J. P., \& Townsend, R. M. (2012). The Impact of Credit on Village Economies. American Economic, Journal: Applied Economics, 4(2), 98-133. https://www.aeaweb.org/articles?id=10.1257/app.4.2.98

Karlan, D., \& Zinman, J. (2010). Expanding Credit Access: Using Randomized Supply Decisions to Estimate the Impacts. Review of Financial Studies, 23(1), 433-464. https://doi.org/10.1093/rfs/hhp092

Khandker, S. R., \& Faruqee, R. R. (2003). The Impact of Farm Credit in Pakistan. Agricultural Economics, 28(3), 197-213. http://dx.doi.org/10.1016/S0169-5150(03)00017-3

Khandker, S. R. (2005). Microfinance and Poverty: Evidence Using Panel Data from Bangladesh. The World Bank Economic Review, 19, 263-286. https://doi.org/10.1093/wber/lhi008

Mahjabeen, R. (2008). Microfinance in Bangladesh: Impact on households, consumption and welfare. Journal of Policy Modeling, 30(6), 1083-1092. http://dx.doi.org/10.1016/j.jpolmod.2007.12.007

Mosley, P., \& Hulme, D. (1998). Microenterprice Finance: is there a conflict between Growth and Poverty Alleviation? World Development, 26(5), 783-790. http://dx.doi.org/10.1016/S0305-750X(98)00021-7

Morduch, J. (1998). Does microfinance really helps the poor? New evidence from Flagship programs in Bangladesh. New York University. New York, NY: NYU Wagner. 
Morduch, J., \& Haley, B. (2002). Analysis of the Effects of Microfinance on Poverty Reduction. NYU Wagner Working Paper No. 1014. New York, NY: NYU Wagner.

Pitt, M., \& Khandker, S. R. (1998). The impact of group-based credit on poor households in Bangladesh: Does the gender of participants matter? Journal of Political Economy, 106(5), 958-996. http://dx.doi.org/10.1086/250037

Robinson, M. S. (2001). The microfinance revolution: Sustainable finance for the poor (Vol. 1). Washington, D.C.: The World Bank.

\section{Notes}

Note 1. See, e.g., Pitt and Khandker (1998), Robinson (2001); Morduch \& Haley (2002); Khandker (2003); Mahjabeen (2008); Armendáriz \& Morduch, (2010); Boonperm, Haughton, Khandker, (2013); and Kaboski and Townsend, (2012).

Note 2. Given the limitation of data it was no possible to distinguish between access to credit from banks or from other institutions.

Note 3. See, e.g., Pitt and Khandker (1998), and Kaboski and Townsend (2012).

Note 4. Cf. ONS 2013, «Recensement général de la population» http://www.ons.mr

Note 5. ONS-ILO Joint Labor Survey, 2013.

Note 6. Mauritania Economic Update 2014, World Bank.

Note 7. World Bank, 2007.

Note 8. Cf. Mauritania Country Partnership Strategy, World Bank, 2013.

Note 9. World Bank. 2013.

Note 10. Ibidem.

Note 11. African Development Fund (2007). Mauritania Appraisal Report, PRECAMF.

Note 12. See also Attanasio, Battistin and Padula (2010) for a discussion.

Note 13. The value of consumption of household production, total spending on nondurable goods and food spending are equivalised considering per capita expenditure. Expenditures are measured in "milliers d'ouguiyas".

Note 14. The analysis below was also performed by region. This is not reported in its entirety for reasons of brevity. Mauritania's territory was divided into three macro zones, by clustering regions: Zone 1 (Nouakchott, Dakhlett Nouadibou) Zone 2 (Gorgol, Brakma, Traza, Guidimagha) and Zone 3 (Hodh Charghy, Hodh Gharby.Assaba, Adrar, Tagant, Tirs-Ezemour, Inchiri). The subdivision in zones reflects various structural characteristics at the subnational level. Zone 1 represents the most populated and urbanized areas, some of the most productive and economically active in the country. Zone 2 corresponds roughly to the Senegal valley regions; these areas are structurally different from the Sahelian regions, as they rely more on agricultural activities and are significantly less sparsely populated than desert areas. Zone 3 is obtained as a residual. The analysis by macro areas showed that the zone 1 presented a positive effect of access to credit on education expenditure and poverty reduction. A negative effect on self-production was found for the other two macro areas.

Note 15. See also Pitt and Khandker (1998) for a discussion.

Note 16. Meaning, if the analysis is repeated by omitting some of the distances, the results do not change.

Note 17. An analogous approach was employed by Becker and Woessmann, (2009), who showed that Protestantism had a strong effect on literacy by using "Distance to Wittenberg" as an instrument for the share of Protestants in each county. They corroborate the identifying assumption by showing that distance to Wittenberg is indeed unrelated to a series of proxies for economic and educational development before 1517, including the pre-Luther placement of schools, universities, monasteries, and free imperial and Hanseatic cities.

Note 18. The analysis was computed between the two variables (separately).

Note 19. Computed from the main sample. 


\section{Copyrights}

Copyright for this article is retained by the author(s), with first publication rights granted to the journal.

This is an open-access article distributed under the terms and conditions of the Creative Commons Attribution license (http://creativecommons.org/licenses/by/4.0/). 